IFN Working Paper No. 858, 2011

\title{
Government Size and Growth: A Survey and Interpretation of the Evidence
}

Andreas Bergh and Magnus Henrekson 


\title{
Government Size and Growth: A Survey and Interpretation of the Evidence
}

\author{
Andreas Bergh ${ }^{1,2}$ and Magnus Henrekson ${ }^{2}$
}

This version: 14 April 2011

\begin{abstract}
The literature on the relationship between the size of government and economic growth is full of seemingly contradictory findings. This conflict is largely explained by variations in definitions and the countries studied. An alternative approach - of limiting the focus to studies of the relationship in rich countries, measuring government size as total taxes or total expenditure relative to GDP and relying on panel data estimations with variation over time - reveals a more consistent picture: The most recent studies find a significant negative correlation: An increase in government size by 10 percentage points is associated with a 0.5 to 1 percent lower annual growth rate. We discuss efforts to make sense of this correlation, and note several pitfalls involved in giving it a causal interpretation. Against this background, we discuss two explanations of why several countries with high taxes seem able to enjoy above average growth: One hypothesis is that countries with higher social trust levels are able to develop larger government sectors without harming the economy. Another explanation is that countries with large governments compensate for high taxes and spending by implementing market-friendly policies in other areas. Both explanations are supported by ongoing research.
\end{abstract}

JEL Classification: E62; H11; H20; O23; O43.

Keywords: Government size; Government expenditure; Economic growth; Economic freedom; Globalization; Taxation.

${ }^{1}$ Research Institute of Industrial
Economics (IFN)
Box 55665
SE-102 15 Stockholm
Phone: +46-8-665 4500
Fax: +46-8-665 4599
e-mail: magnus.henrekson@ifn.se

\author{
${ }^{2}$ Department of Economics \\ Lund University \\ P.O. Box 7082 \\ SE-220 07 Lund \\ e-mail: andreas.bergh@ifn.se
}

\footnotetext{
*We are grateful for skilful research assistance from Nina Öhrn. Financial support from the Jan Wallander and Tom Hedelius Research Foundation Is gratefully acknowledged.
} 


\section{Introduction}

For decades there has been an intense debate regarding the relationship between government size and economic growth. The state of research is seemingly contradictory, with some scholars asserting that big government decreases growth, and others denying this to be the case.

A close look at the literature reveals these arguments are not as conflicting as they at first appear. Two important differences in existing research concern the measurement of government size and the type of countries studied (rich or poor). When we exclusively focus on studies that examine the correlation between growth of real GDP per capita and total government size over time in rich countries (OECD and equally rich), the research is rather close to a consensus: the correlation is negative, and the sign seems not to be an unintended consequence of reverse causality.

The negative correlation has yet to be reconciled with the fact that big government is clearly correlated with higher levels of affluence. The aggregate correlation between government size and growth is also less policy relevant because political decisions are made on specific taxes and expenditure items, rather than aggregates. There are also strong theoretical reasons to expect different types of taxes and expenditures to have differential growth effects.

In this survey, we review a wide body of literature on the subject and probe deeper into the debate. The focus is on the most recent papers that deal with the relationship between growth and government size. Our survey shows in general that it matters what governments actually do and how they finance their activities; and that the most recent studies typically find a negative correlation between total government size and economic growth.

Having established this, we turn to the issue of causality and note that the correlation seems not to be driven by the most obvious sources of reverse causality, such as automatic stabilizers increasing government expenditure in economic downturns. Finally, we turn to the record of the Scandinavian welfare states, which during the last ten to fifteen years have mysteriously done reasonably well in terms of growth. Based on our survey, we propose two possibly complementary explanations: selection and compensation. The selection hypothesis suggests that countries that can successfully develop and maintain large government sectors are more likely to do so. The compensation hypothesis suggests that countries with big government can enjoy high growth by applying market-friendly policies in other areas.

\section{Theoretical considerations}

Over time, economists have accumulated considerable knowledge about what explains growth. Three main perspectives can be identified: Neoclassical growth models, endogenous growth theory, and institutions as fundamental determinants of growth.

\subsection{Neoclassical and endogenous growth theory}

In neoclassical models (pioneered by Solow 1956 and Swan 1956), there are diminishing returns to capital and the long-term growth rate is exogenous. Novel or higher taxes will affect GDP by creating a distortion in the form of a wedge between supply and demand. As a result, some transactions that would take place without the tax will not take place when the tax is levied. However, this effect is 
static and when taxes are constant (at any level) the economy will grow at a rate determined by exogenous technological progress. ${ }^{1}$

Because neoclassical growth models omit the factors that explain long-term growth they are sometimes viewed as at best less useful and at worst inadequate. Nevertheless, even static policy effects can be sizeable, affecting the level of savings or the level of employment. According to Feldstein (2006) considering that taxable income is probably more responsive than hours worked, ${ }^{2}$ static welfare costs of taxation may be large. Also, effects that in the theoretical model appear as "temporary" may still last for twenty years or more as the economy adjusts to a new steady state. ${ }^{3}$

In endogenous growth models (pioneered by Romer 1986), the production function is specified without diminishing returns. As a consequence, anything that affects the level of technology also affects the long-run per capita growth rate. This means the growth effects of distortionary tax wedges are conceivably far greater than in neoclassical growth models. According to King and Rebelo (1990), the welfare cost of a 10 percent increase in the income tax rate can be forty times greater in basic endogenous growth models than in neoclassical growth models.

On the other hand, the potential growth gains from what Barro (1990) calls productive government spending is also higher in endogenous models. Hence, the negative effects of higher taxes may be partly or completely offset by government spending on, for example, education and health care, which may lead to higher long-term growth as they enter growth models as higher levels of technology. In other words, as taxes cause dynamic efficiency losses through effects on occupational choice, schooling attainment, and other decisions that affect the accumulation of human capital, these effects may partly or completely be offset by public expenditure on education.

\subsection{Institutions as fundamental determinants of growth}

The most recent trend involves investigating the role of institutions on economic growth. Several studies, following works like North (1987), have tested and found strong support for the idea that certain fundamental institutional arrangements are crucial for economic growth - probably the most important being the rule of law and well-functioning property rights. The critical role of the latter as more important for growth than factors such as geography and trade was stressed in a famous paper by Rodrik et al. (2004).

Successive literature reviews by Armey (1995), Abdiweli (2003) and Asoni (2008) have confirmed the consensus that institutions matter for growth. In addition to the importance of well-defined property rights, Abdiweli empirically confirmed that judicial efficiency, low levels of corruption and a wellorganized public bureaucracy also co-vary positively with high levels of growth. The risks of a breach of contract or government expropriation have clear negative effects on growth, according to Abdiweli.

\footnotetext{
${ }^{1}$ As emphasized by Plosser (1992), capital formation is likely to be quantitatively more important for long-run growth rates than the original Solow (1956) model suggested. Hence, the crowding out of private investment in human and physical capital by government spending and taxation could have a sizeable effect on the rate of economic growth.

${ }^{2}$ For example, if the marginal tax rate is raised, a person may not only choose to work fewer hours, but also turn down an offer for promotion, learn fewer new productive skills, take longer breaks, or work at a lower intensity. All these adjustments may be at least as important as working fewer hours in inducing a lowering of taxable income when the marginal tax rate is raised.

${ }^{3}$ Barro and Sala-i-Martin (2004) estimate empirically, based on data at different levels of aggregation, that it takes 25 to 35 years to eliminate one-half of the deviation from the steady state.
} 
In another important survey, Doucouliagos and Ulubasoglu (2006) review and evaluate fifty-two other studies that examine the link between economic freedom (measured in several different ways) and growth. They conclude that economic freedom "has a robust positive effect on economic growth regardless of how it is measured" (p. 68). Berggren and Jordahl (2005) compare different types of economic freedom, and find the security of property rights and integrity of the legal system the conditions most closely related to growth.

In the economics literature the relationship between the concepts "institutional quality" and "economic freedom" is somewhat ambiguous. Institutional quality is the broader term, not clearly defined simply because we do not know exactly what types of institutions are beneficial. On the other hand, economic freedom typically refers to the Economic Freedom Index (EFI) of the Fraser Institute, a commonly used index that quantifies certain aspects of economic freedom. As Gwartney et al. (2004) point out, the EFI measures both longer-term institutional variables, such as the quality of the legal system, and shorter-term public policies, such as marginal tax rates. The term "institutional quality" is often used to refer to both.

Whether levels of or changes in institutional quality matter more for growth is a source of disagreement. In two overlapping papers, De Haan and Sturm (2000) and Sturm and De Haan (2001) conduct a series of thorough analyses of the relationship between economic freedom and growth. Applying extreme bounds analysis, ${ }^{4}$ their overall finding is that the level of economic freedom is not robustly related to economic growth, but that changes in economic freedom have a robust impact. On the other hand, Dawson (2003) uses so-called Granger tests to assess the relationship, finding that the level of economic freedom, especially the level of property rights, is an important cause of economic growth. So far, no consensus has emerged.

There has also been some critique of the institutional focus in growth research. While there is clearly a correlation between institutional indicators and growth, Glaeser et al. (2004) argue that the instrumental variable techniques used to establish causality are flawed. They also contend human capital is more important than institutions for explaining growth. For incisive discussion of the debate on institutions and growth, and views on how to best advance research, see, for example, Pande and Udry (2005) and Rodrik (2007).

It is critical to recognize that these three perspectives on growth do not contradict one another, but rather emphasize different aspects of the causes of growth. From neoclassical models we learn government policies that affect savings or labor force participation have temporary effects on growth, but no effects on the long-run level of technological progress. From endogenous models, we learn the effects may be permanent, and thus it matters crucially what governments do: Expenditures on education that increase the level of human capital may lead to permanently higher growth rates, but the taxes needed to finance them may have a negative impact on long-run growth levels. ${ }^{5}$ From the recent focus on institutions we learn that in addition to what governments do, it is important how it is done: Transparent rules, rule of law and well-defined property rights seem to be conducive to growth regardless of government size.

\footnotetext{
${ }^{4}$ The so-called extreme bounds analysis (EBA) was pioneered by Levine and Renelt (1992) in the context of cross-country growth regressions. The EBA is performed by systematically, but mechanically, running a large number of regressions with different combinations of conditioning variables among the regressors, to test whether all specifications yield a significant relationship between the main explanatory variable and the dependent variable. An extension of the EBA analysis was suggested by Sala-i-Martin (1997), the basic idea of which is to examine the distribution of coefficient estimates rather than use an absolute criterion of robustness.

${ }^{5}$ Endogenous growth models also demonstrate the theoretical possibility of poverty traps, as a result of multiple equilibria.
} 


\subsection{Government size and economic growth}

Economic theory thus suggests several mechanisms by which government activity can affect growth. However, these mechanisms do not suggest an unambiguous link between government size and growth. In fact, there are many reasons to expect a relationship that is inversely U-shaped, a hypothesis sometimes referred to as the Armey-curve (Armey 1995).

At the bottom rung of less developed countries there appears to be a positive association between tax revenue and growth because a state typically succeeds in collecting taxes when successful at providing the stability necessary for economic activity to start growing (Besley and Persson 2009). The most basic tasks for government, such as protecting property rights and the rule of law, can be accomplished at low levels of taxation. When such a minimal Hobbesian state expands to providing things like infrastructure, basic health care and education, the effect of government size on growth is more likely positive than negative. However, if productive government expenditures are characterized by decreasing returns, the negative effect of taxes to finance public expenditure may at some point dominate the positive effect of growth-promoting government activities.

There are also reasons to expect the marginal negative effect of government size to increase in absolute terms as government grows. For example, Agell (1996) noted the distortionary effect of taxation is proportional in size to the squared tax rate. Distortions are small for low levels of taxation, but as taxes increase they grow rapidly, beyond a certain point becoming extremely large. An additional reason to expect rich countries to show a negative correlation comes from the mechanism suggested by Olson (1982): Organized interest groups tend to evolve, and strive to obtain advantages for themselves in the form of legislation or transfers which have a side effect, retarding the normal functioning and growth of the market economy. The scope for interest group action of this kind is likely to be greater in countries with larger public sectors. This situation is compounded as the public sector grows, as the potential profits from rent-seeking activities are larger. This may lead to a greater diversion of resources into unproductive use (Buchanan 1980).

There are thus several theoretical reasons to uphold the following contrasting pattern:

- In poor countries, public sectors are typically small, and the relationship between government size and growth is positive.

- In rich countries, public sectors are typically large, and the relationship between government size and growth is less positive than in poor countries, and possibly negative.

Let us now turn to the empirical question: Have western democracies reached a point where government size becomes an impediment to growth?

\section{What do existing studies show?}

While we may infer from the theoretical discussion that different types of expenditure and taxes are likely to have different growth effects, we start by describing studies that examine the aggregate correlation between total government size and growth in rich countries. We first briefly survey some of the pioneering studies that measure government size as the sum of all public expenditure or taxes (local, regional, and central) in all areas, and then move on to more recent work. 


\subsection{Early cross-country studies}

A number of early cross-country studies have found a negative relationship between government size and economic growth, summarized in Table 1.

Table 1. Early cross-country studies

\begin{tabular}{|c|c|c|c|}
\hline Study & $\begin{array}{l}\text { Measure of } \\
\text { government size }\end{array}$ & $\begin{array}{l}\text { Number of countries } \\
\text { and time period }\end{array}$ & Result-summary \\
\hline Cameron (1982) & Public consumption & 19 countries, $1960-79$ & Negative \\
\hline Landau (1983) & Public expenditure & 48 countries, $1961-76$ & Negative \\
\hline Marlow (1986) & $\begin{array}{l}\text { Total expenditure, } \\
\text { social expenditure } \\
\text { (both levels and } \\
\text { growth) }\end{array}$ & 19 countries, $1960-80$ & Negative \\
\hline Saunders (1986) & $\begin{array}{l}\text { Same as Marlow } \\
\text { (1986) }\end{array}$ & $\begin{array}{l}14-21 \text { countries, } \\
1960-73 \text { and } 1975-82\end{array}$ & $\begin{array}{l}\text { Previous results sensitive } \\
\text { to the choice of time } \\
\text { period and countries }\end{array}$ \\
\hline Saunders (1988) & $\begin{array}{l}\text { Same as Marlow } \\
\text { (1986) }\end{array}$ & $\begin{array}{l}15-17 \text { countries, } \\
1960-1980\end{array}$ & $\begin{array}{l}\text { Previous results sensitive } \\
\text { to the choice of time } \\
\text { period and countries }\end{array}$ \\
\hline Agell et al. (1997) & $\begin{array}{l}\text { Tax and expenditure } \\
\text { as a share of GDP }\end{array}$ & $\begin{array}{l}\text { 22-23 OECD countries, } \\
1970-90\end{array}$ & $\begin{array}{l}\text { The negative correlation } \\
\text { not robust to controlling } \\
\text { for initial GDP and } \\
\text { demography }\end{array}$ \\
\hline
\end{tabular}

Cameron (1982) is an early simple study, presenting a negative bivariate correlation between the average percentage of GDP spent by government and the average rate of growth in real GDP over the period 1960-79. Cameron argued the size of the effect was not very large, noting that "a very dramatic increase in spending, in the range of 20 percentage points of GDP - a magnitude of increase that occurred in a few nations such as Sweden, the Netherlands, and Denmark - would have reduced the rate of economic growth by only one percent[age point]."

Landau (1983), after increasing the number of countries, adding control variables for education and energy consumption and some geographic dummies, confirmed the negative correlation. Marlow (1986, p. 152), controlling only for level and growth of social expenditure, concluded that "[a]nalysis of government expenditure data of 19 industrialized countries over the period 1960-1980 supports the view that public sector size retards overall economic growth."

The evidence and arguments generated in early studies, typically strictly limited to cross-country regressions with no (or occasionally very few) control variables, is at most merely indicative of what is going on. As originally noted by Saunders (1986) the existing cross-country evidence was not sufficiently robust to incorporate variations in the measure of government size selected, the timeperiod investigated or the countries included in the sample. Subsequently, Saunders (1988) criticized Marlow (1986) by pointedly noting "the extreme sensitivity of Marlow's results to the countries included in the sample (particularly Japan), to the time period, and to the other variables included in the analysis" (p. 284). 


\subsection{Fixed effects panel studies}

Eventually, as more data became available, research moved to panel data where effects are estimated using information representing changes within countries over time; Table 2 summarizes seven such studies. By assuming that omitted variables that cause variation in growth among countries are constant within each country, we can remain ignorant about what these variables are inasmuch as their influence on growth is picked up by the country fixed effect.

The so-called fixed effects methodology has an obvious potential downside, namely the sheer inefficiency of not using cross-sectional information in the data. If only little variation occurs in government size within countries over time, studies of fixed effects may falsely claim they are phantoms, arguing there are very few if any negative growth effects from government size. In some cases, estimates using only within-country variation do not significantly differ from estimates also using cross-country variation. In this case, when a random effects model where between-country variation is also used, data is exploited more efficiently. ${ }^{6}$ Table 2 shows one study where the preferred specification is random effects: Dar and AmirKhalkhali (2002).

To our knowledge, the seven studies in Table 2 are the only ones that satisfy the following criteria:

- Published in peer-reviewed journals after 2000

- Use panel data

- Focus on rich countries (i.e., EU, OECD or equally rich countries) ${ }^{7}$

- Measure total government size (i.e., total taxes or total expenditure)

- Examine the effect of government size on growth of real GDP per capita.

As can be seen, five out of seven studies find a negative correlation between government size and growth. While the longest time period is covered by Romero-Avila and Strauch (2008), the total number of country years is highest in the studies by Afonso and Furceri (2010) and Bergh and Karlsson (2010). We will return to these studies below, but first some words on the two studies that deviate in their results.

Agell's et al. (2006) replication and critique of Fölster and Henrekson (2001) led to a provocative rejoinder by Fölster and Henrekson (2006). The conclusion to be drawn from the debate is that the correlation may be significantly less robust when only OECD-countries are investigated, a point that deserves to be taken seriously. The OECD countries are not a random sample of rich countries. They are, in fact, unified by their commitment to democracy and a liberal market economic system, working consciously to boost growth and living standards. Thus, the fact that adding seven equally wealthy non-OECD/non-OPEC countries to the analysis gives a more robust negative correlation strengthens the view such a correlation actually exists.

\footnotetext{
${ }^{6}$ Typically, the Hausman test is used to examine if the RE and FE estimates are very different, in which case the $R E$ assumption is probably invalid and FE should be used.

${ }^{7}$ Focusing on cross-country studies, we do not cover studies dealing with US states such as the recent study by Besley et al. (2011).
} 
Table 2. Recent panel data studies

\begin{tabular}{|c|c|c|c|}
\hline Study & $\begin{array}{l}\text { Measure of } \\
\text { government size }\end{array}$ & $\begin{array}{l}\text { Number of } \\
\text { countries and time } \\
\text { period }\end{array}$ & Conclusion \\
\hline $\begin{array}{l}\text { Fölster and } \\
\text { Henrekson } \\
(2001)\end{array}$ & $\begin{array}{l}\text { Total tax revenue, } \\
\text { total government } \\
\text { expenditure }\end{array}$ & $\begin{array}{l}22-29 \text { rich countries } \\
\text { ( } 7 \text { rich non-OECD } \\
\text { countries used as } \\
\text { robustness test), } \\
1970-95 .\end{array}$ & $\begin{array}{l}\text { Robust and significant negative effect } \\
\text { from government expenditure. Less } \\
\text { robust negative effect for total tax } \\
\text { revenue. }\end{array}$ \\
\hline $\begin{array}{l}\text { Dar and } \\
\text { AmirKhalkhali } \\
(2002)\end{array}$ & $\begin{array}{l}\text { Total government } \\
\text { expenditure }\end{array}$ & $\begin{array}{l}19 \text { OECD countries, } \\
1971-99 .\end{array}$ & $\begin{array}{l}\text { Significant negative effect for the } \\
\text { entire period, as well as separately for } \\
\text { the } 1970 \text { s and the } 1980 \text { s. For the } 1990 \mathrm{~s} \\
\text { separately, no significant effect is } \\
\text { found. The authors also run country- } \\
\text { specific regressions, finding a } \\
\text { significant negative effect for } 16 \text { of } 19 \\
\text { countries.* }\end{array}$ \\
\hline $\begin{array}{l}\text { Agell et al. } \\
\text { (2006) }\end{array}$ & $\begin{array}{l}\text { Total tax revenue, } \\
\text { total government } \\
\text { expenditure }\end{array}$ & $\begin{array}{l}22-23 \text { OECD } \\
\text { countries, } 1970-95 .\end{array}$ & $\begin{array}{l}\text { Results in Fölster and Henrekson } \\
(2001) \text { are weaker when only including } \\
\text { OECD countries and cannot be given a } \\
\text { causal interpretation due to } \\
\text { simultaneity. }\end{array}$ \\
\hline $\begin{array}{l}\text { Romero-Avila } \\
\text { and Strauch } \\
(2008)\end{array}$ & $\begin{array}{l}\text { Total and } \\
\text { disaggregated } \\
\text { revenue, total and } \\
\text { disaggregated } \\
\text { expenditure }\end{array}$ & $\begin{array}{l}15 \text { EU countries, } \\
\text { 1960-2001, annual } \\
\text { data. }\end{array}$ & $\begin{array}{l}\text { For total revenue and total expenditure: } \\
\text { negative and significant effect. } \\
\text { Negative and significant for direct } \\
\text { taxes, insignificant for indirect taxes } \\
\text { and social security contributions. } \\
\text { Negative and significant effect from } \\
\text { government consumption and transfers, } \\
\text { significant positive effect from } \\
\text { government investments. }\end{array}$ \\
\hline $\begin{array}{l}\text { Colombier } \\
(2009)\end{array}$ & $\begin{array}{l}\text { Total tax revenue, } \\
\text { total government } \\
\text { expenditure }\end{array}$ & $\begin{array}{l}21 \text { OECD countries, } \\
1970-2001 .\end{array}$ & $\begin{array}{l}\text { Finds "a stable positive, albeit small, } \\
\text { growth effect of government size" (p. } \\
\text { 910); result rebutted by Bergh and } \\
\text { Öhrn (2011). }\end{array}$ \\
\hline $\begin{array}{l}\text { Afonso and } \\
\text { Furceri (2010) }\end{array}$ & $\begin{array}{l}\text { Total public } \\
\text { revenue and } \\
\text { expenditure }\end{array}$ & $\begin{array}{l}28 \text { OECD and EU } \\
\text { countries, } \\
1970-2004 .\end{array}$ & $\begin{array}{l}\text { Both the share and volatility of } \\
\text { government revenue and spending is } \\
\text { detrimental for growth. }\end{array}$ \\
\hline $\begin{array}{l}\text { Bergh and } \\
\text { Karlsson } \\
\text { (2010) }\end{array}$ & $\begin{array}{l}\text { Total public } \\
\text { revenue and } \\
\text { expenditure }\end{array}$ & $\begin{array}{l}24-27 \text { OECD } \\
\text { countries 1970-1995, } \\
\text { and 1970-2005. }\end{array}$ & $\begin{array}{l}\text { Negative effect of taxes and } \\
\text { expenditure robust in a BACE-analysis } \\
\text { (see section } 3.4 \text { ). }\end{array}$ \\
\hline
\end{tabular}

* For three out of 19 countries, the authors report a non-significant relationship: negative but insignificant for Norway and Sweden, positive but insignificant for the United States.

Furthermore, the controversy is centered on regressions using first differences. As pointed out by Barro (1997), first differencing tends to emphasize measurement error over signal, and measurement error when using first differences of explanatory variables in the regression tends to bias the estimated coefficient of these variables toward zero. 
However, to be entirely fair, what is beyond dispute is that the main thrust of the Agell et al. (2006) critique did not concern the sign of the partial correlation, but rather the issue of whether or not the results can be given a causal interpretation. We return to the issue of causality below.

The study by Colombier (2009) stands out in arguing that government size has not been detrimental to growth among OECD countries. Colombier claims to have found a small positive effect, and explains this strongly divergent result by maintaining other studies that use least square estimators are "biased and inefficient" (p. 910) in contrast to the robust modified M-estimator of Yohai et al. (1991) that he effectively puts to work. However, Bergh and Öhrn (2011) in a thorough attempt to replicate this study conclude the results are in fact not driven by the econometric method, but depend rather on the omission of time fixed effects and other control variables. Bergh and Öhrn demonstrate that adding time fixed effects, even with the alternative estimator deployed by Colombier, produces a negative partial correlation in line with what other studies have found. Adding controls for inflation, unemployment and economic openness typically does not change this and often tends to increase the size of the negative coefficient on total tax revenue.

\subsection{Disaggregating the effects}

Some of the papers described in Table 2 probe deeper into the issue by disaggregating government revenues and expenditure. Afonso and Furceri (2010) analyze how several revenue and expenditure sources, measured as a percentage of GDP and in terms of their business-cycle volatility, directly relate to growth. They find that indirect taxes, social contributions, and government consumption have a sizeable, negative and statistically significant effect on growth, both in terms of size and volatility. Whereas for subsidies only their size matters for growth, for government investment only volatility matters. Thus, government investment per se is not bad for growth, but if it is highly volatile, growth on average suffers.

Romero-Avila and Strauch (2008) analyze data representing a smaller set of countries (EU15) dating from 1960. They find direct taxes have negative and significant effects, but indirect taxes and social security contributions have no significant effects. These findings are in line with other studies looking at the relationship between tax structure and growth. For example, Widmalm (2001) finds that taxes on personal income as a share of total tax revenue and more progressive taxes impede growth. For expenditure, Romero-Avila and Strauch (2008) find government consumption and transfers have a significant negative effect, and government investment has a significant positive effect.

Bergh and Öhrn (2011) use Colombier's data to argue that direct (rather than indirect) taxes drive a negative correlation between taxes and growth. The effects found in these studies are consistent with older evidence. Hansson and Henrekson (1994) examined fourteen rich countries over the 1970-1987 period, and concluded that government transfers, consumption, and total expenditure are consistently negatively related to growth of total factor productivity, whereas educational expenditure has a positive effect.

\subsection{Using BACE to handle the model selection problem}

As already noted, an important methodological lesson from early cross-country studies is that results are highly sensitive to what other variables are included in the model. Ideally, a theoretical approach gives sufficient guidance regarding the empirical specification, but in practice there is no theoretical agreement on how growth regressions should be specified and what variables should be included. 
A bold take on the model selection problem in growth regressions is the method called Bayesian averaging of classical estimates (BACE), developed and first used by Doppelhofer et al. (2004). They noted that while several variables have been said to affect growth, many of these are significant only in some regressions. The authors therefore constructed an algorithm to automatically run tens of thousands of different regressions, each of which selects a subset of variables from a set of sixty-seven factors that potentially explain economic growth. There are of course $2^{67}$ different possible models. Using a standard approach, any researcher would have the time and patience to run perhaps at most a thousand of these, and then select a few regressions suitable for the study. Needless to say, one might expect a researcher wishing to find a negative effect of a particular variable to be more inclined to opportunistically include this variable in the regression, and to show results that had the desired sign.

The BACE algorithm handles the problem by requiring the researcher to supply one single parameter: the number of explanatory variables to be included in the model. The algorithm then runs regressions and generates the average coefficient for each variable, weighted by the goodness-of-fit of each model. The Bayesian algorithm initially treats all variables as equally likely to be included in the model, but the inclusion probability of each variable is updated based on the goodness of fit for regressions with the variable included. Conditional on inclusion, the BACE algorithm will give the coefficient based on a weighted average, where weights are determined by how well each possible model explains the data. According to the BACE-algorithm, variables that increase their inclusion probability during the process are considered robust. The researcher can test the robustness of results by simply varying the model size, typically from three to seven variables, and checking if the same variables increase their inclusion probability.

Doppelhofer et al. applied the BACE method to a sample of 88 countries with growth averaged over the time period 1960-96. Among the 67 variables, 14 were robust in the sense just described. Large effects were found for life expectancy, education, initial GDP and a number of geographic dummy variables. Among the variables with a negative effect, they found a small negative effect of the initial level of government consumption, but not of the total government spending share of GDP. These comparative findings are noteworthy, but not of primary significance here because the sample incorporated data from both rich and poor countries.

However, Bergh and Karlsson (2010) adapt the BACE method to panel data, applying it to the dataset used by Fölster and Henrekson (2001) which they update by adding ten years of observations. They run the algorithm on the original (1970-95) and updated datasets (1970-2005), finding four variables robust in both: Total tax revenue, initial GDP per capita, inflation, and gross savings as a share of GDP (all variables except savings were negatively correlated with growth).

There are two reasons for placing greater reliance on the results from the earlier dataset in the Bergh and Karlsson (2010) study. First, this period includes the growth period that several high tax countries experienced after the crisis of the early 1990s, while the period 1970 to 1995 coincides with a period when some high tax countries such as Sweden were lagging behind. Second, this dataset uses updated data for all years, not only adding the years $1996-2005 .{ }^{8}$ During the 1970 to 2005 period, two further variables are deemed robust when using both taxes and expenditure to measure government size: The average annual growth rate of the labor force and exports as a share of GDP.

\footnotetext{
${ }^{8}$ The picture of the growth of a particular country in the 1970s, when viewed in terms of OECD data from the 1990 s, in some cases differs from the growth according to more recently revised data sets. Presumably, data quality increases over time as a result of such revisions.
} 


\subsection{Is the negative correlation due to reverse causality?}

A negative correlation between government size and economic growth does not imply causality. In fact, the most obvious reason (among many) to suspect reverse causality a problem is that in welfare states social insurance schemes act as automatic stabilizers. In general, in times of economic downturn social expenditure provides stabilizers that automatically undermine the government's balanced budget. On the other hand, in boom years when growth rates are higher, fewer people will be unemployed, and public expenditure shares will be lower. For this reason, a negative correlation between public expenditure and economic growth is to be expected in the short run. Finding a negative correlation is therefore no proof that high expenditure causes low growth.

Attempts are made to avoid the problem of capturing effects caused by business cycle fluctuations and automatic stabilizers by designing specific regressions for the analysis. To some extent this is done by averaging growth over several years, or by controlling for the business cycle itself by including some measure of it such as unemployment or capacity utilization. ${ }^{9}$

There is, however, another approach noted by several authors: The reverse causality bias described above for public expenditure runs in the opposite direction for tax revenue. Given that most countries have at least slightly progressive tax schedules, the elasticity of tax revenue with respect to GDP is above unity. When growth increases, tax revenue will increase disproportionately, and the ratio of tax revenue to GDP will rise. Moreover, when the economy is booming, the taxation of capital gains and profits results in higher revenue. While both of these effects imply high taxes tend to correlate positively with rapid growth, in fact causality runs from growth to tax revenue, not the other way around.

The main lesson to be learned from exploring these important mechanisms is that a negative coefficient on government expenditure in growth regressions need not imply that large government causes slower growth. On the other hand, a negative coefficient on taxes actually provides rather strong evidence that high taxes cause lower growth, because reverse causality leads us to expect a positive correlation. Bergh and Karlsson (2010) discuss this issue at some length, noting in their analysis that taxes are actually more robust than expenditure. ${ }^{10}$ In general, however, the BACEapproach does not solve the issue of endogeneity. Romero-Avila and Strauch (2008) also discuss this potential problem, test the robustness by using annual data that are cyclically adjusted in several ways. They find no evidence of a systematic bias due to automatic stabilizers, even though the results are sensitive to the method used for creating cyclically adjusted data: Applying a HP-filter actually yields a significant positive effect on direct taxes as well as a significant negative effect on social transfers. These are precisely the results that should occur when automatic stabilizers operate.

There are other reasons beyond automatic stabilizers for expecting problems of endogeneity bias in this literature. Most studies thus use instrumental variables to create a variation in government size that ideally can be used to properly identify the causal effect. In this case the task is to find some variable or variables that are correlated with government size, but not with economic growth, and then use the variation in these instrumental variables to predict government size. Finally, a second-stage regression examines whether these predicted values have a negative effect on growth. Table 3 summarizes how various studies deal with the endogeneity problem.

\footnotetext{
${ }^{9}$ However, a related study by Mollick and Cabral (2011) on the growth effects of public consumption argues that averaging data may underestimate the growth effect.

${ }^{10}$ See Durevall and Henrekson (2011), who test for such asymmetric effects on annual data from the early 19th century until the present in Sweden and the UK. They find no consistent evidence period of an increase in government spending as a share of GDP resulting from expansionary fiscal policy in recessions.
} 
Table 3. Tackling the problem of endogeneity

\begin{tabular}{lll}
\hline Study & Method used & Results \\
\hline $\begin{array}{l}\text { Afonso and Furceri } \\
\text { (2010) }\end{array}$ & $\begin{array}{l}\text { Instrument the share of government spending and } \\
\text { revenue by its lagged value, openness and country size } \\
\text { (measured as total population), noting that country } \\
\text { size is a robust determinant of government size }\end{array}$ & $\begin{array}{l}\text { The size of the coefficients } \\
\text { decrease somewhat, but } \\
\text { both taxes and revenue } \\
\text { remain negative and } \\
\text { (Alesina and Wacziarg 1998) and as argued by Rose } \\
\text { significant for both the EU } \\
\text { (2006) has no statistically significant effect on growth. } \\
\text { and the OECD. }\end{array}$ \\
$\begin{array}{ll}\text { Generalized Method of Moments (GMM) (Arellano } \\
\text { Strauch (2008) }\end{array}$ & $\begin{array}{l}\text { Confirm a significant } \\
\text { and Bond 1991). This method estimates effects using } \\
\text { first differences with lagged levels used as instruments } \\
\text { for the first-differenced data. }\end{array}$ & $\begin{array}{l}\text { social transfers and gov- } \\
\text { ernment consumption, and }\end{array}$ \\
& $\begin{array}{l}\text { a significant positive effect } \\
\text { of public investments. }\end{array}$ \\
Fölster and Henrekson & $\begin{array}{l}\text { A two stage least squares regression (2SLS) using first } \\
\text { differences, where the first difference of the tax and } \\
\text { public expenditure variables are instrumented by their } \\
\text { lagged levels, and also by fixed country effects, levels } \\
\text { and differences of the population and initial GDP }\end{array}$ & $\begin{array}{l}\text { Significant negative effects } \\
\text { for both taxes and } \\
\text { expenditure. }\end{array}$ \\
& variables. & \\
\hline
\end{tabular}

The lack of good instruments for government size means the issue of causality has not yet been completely settled — and is perhaps not likely to ever do so. ${ }^{11}$ This problem plagues many econometric studies of important phenomena, inhibiting researchers from giving reasonable causal interpretations even to strong correlations.

\subsection{How big is the effect?}

Ziliak and McCloskey (2004) emphasize that the issue of statistical significance may well be of less interest if the size of the effect is not economically significant. Table 4 compares the magnitudes of the four most robust factors in the Bergh and Karlsson study, showing how much annual growth would change if the variable were to increase by one standard deviation.

We see that among the countries in the sample inflation varies substantially and seems detrimental to growth. We also notice that the relative income of a country is important: Those richer than the OECD average grow more slowly, and those poorer grow more rapidly.

More interestingly, one standard deviation higher tax revenue is associated with an annual growth rate that is nine-tenths of a percentage point lower. Given that a standard deviation in this sample is nine percentage points, we could simply say countries where tax revenue is ten percentage points higher on average experience an average growth rate that is one percentage point lower. As shown in Table 5,

\footnotetext{
${ }^{11}$ Recently, techniques have been developed that use variables already existing in the dataset as instruments by transforming them in various ways. One such estimator that is currently very popular is the GMM (generalized method of moment) system estimator that jointly estimates the system with first-difference equations instrumented by lagged levels, and level equations instrumented by first-differences; see Arellano and Bover (1995) and Blundell and Bond (1998). On the other hand, Roodman (2009) cautions that flawed use of this estimator may produce erroneous results.
} 
the five studies that find a negative effect are in relative agreement about size: 10 percentage points higher taxes (or public expenditure) is associated with 0.5 to 1 percentage point lower annual growth. It is noteworthy that the size of the effect is very similar to the simplistic early Cameron (1982) study.

Table 4. The growth effects of four variables found robust by Bergh and Karlsson (2010)

\begin{tabular}{lrrr}
\hline Variable & Mean & $\begin{array}{r}\text { Standard } \\
\text { deviation }\end{array}$ & Effect \\
\hline Tax revenue, share of GDP (\%) & 33.6 & 8.7 & -0.9 \\
Initial per-capita income relative to the & 1 & 0.29 & -2.0 \\
OECD average & & & \\
Inflation & 0.08 & 0.16 & -2.7 \\
Gross national saving, share of GDP & 0.24 & 0.08 & 0.2 \\
\hline
\end{tabular}

Note: Effect measures the estimated growth effect (in percentage points) of an increase of one standard deviation in the variable in question.

Table 5. Comparison of estimates in different studies—Dependent variable: Annual growth rate of real GDP per capita

\begin{tabular}{|c|c|c|}
\hline Study & $\begin{array}{l}\text { Coefficient on total } \\
\text { taxes/GDP }\end{array}$ & $\begin{array}{l}\text { Coefficient on total } \\
\text { expenditure/GDP }\end{array}$ \\
\hline Afonso and Furceri (2010) & & \\
\hline IV-estimates, OECD (table 10) & -0.09 (significance $1 \%$ ) & -0.09 (significance $1 \%$ ) \\
\hline IV-estimates, EU (table 10) & -0.09 (significance $10 \%$ ) & -0.06 (significance $5 \%$ ) \\
\hline $\begin{array}{l}\text { Bergh and Karlsson }(2010)^{*} \\
\text { (BACE, OECD, 1970-95). }\end{array}$ & -0.11 & Not robust \\
\hline $\begin{array}{l}\text { Bergh and Karlsson (2010) } \\
\text { (BACE, OECD, 1970-2005). }\end{array}$ & -0.10 & -0.09 \\
\hline $\begin{array}{l}\text { Fölster and Henrekson (2001, table 2) } \\
\text { (Fixed effects panel, OECD, 1970-95) }\end{array}$ & -0.05 (not significant) & -0.07 (significant at $5 \%$ ) \\
\hline $\begin{array}{l}\text { Romero-Avila and Strauch (2008, table } \\
\text { 5) (Fixed effects panel, EU15, 1960- } \\
\text { 2001) }\end{array}$ & $\begin{array}{l}-0.06 \text { to }-0.07 \\
\text { (significant at } 5 \% \text { or } 1 \% \text { ) }\end{array}$ & -0.05 (significant at $1 \%$ ) \\
\hline $\begin{array}{l}\text { Dar and AmirKhalkhali (2002, table } 3 \text { ) } \\
\text { (Random effects panel, } 19 \text { OECD } \\
\text { countries, 1971-99) }\end{array}$ & n.a. & $\begin{array}{l}\text { Significant negative effects in } \\
16 \text { out of } 19 \text { countries: from } \\
-0.05 \text { in Finland and Belgium } \\
\text { to }-0.16 \text { in Portugal }{ }^{* *}\end{array}$ \\
\hline
\end{tabular}

\footnotetext{
* The BACE-method in this paper is focused on inclusion probability, not statistical significance (section 3.4).

** The authors report for 3 of the 19 countries surveyed a non-significant relationship: negative but insignificant in Norway and Sweden, positive but insignificant in the US.
}

\subsection{Conclusion-towards a consensus?}

In our view, the most convincing studies are those most recently published. Romero-Avila and Strauch (2008), Afonso and Furceri (2010) and Bergh and Karlsson (2010) use long time periods, examine similar countries, use recent data and check the robustness of their results in several ways. RomeroAvila and Strauch and Afonso and Furceri also check their results for reverse causality. In general, research has come very close to a consensus that in rich countries there is a negative correlation between total government size and growth. It appears fair to say that an increase in total government 
size of ten percentage points in tax revenue or expenditure as a share of GDP is on average associated with an annual lower growth rate of between one-half and one percentage point.

The fact that many scholars still describe the debate as lacking consensus can be attributed to the way they routinely ignore the fact the studies they rely on use a variety of different measures of government size. For example, Lindert (2004) discusses the size of the welfare state according to a very specific definition, without taking into account total government size. Another example is the survey by Gordon and Wang (2004), who describe the literature as conflicting, noting that Agell et al. (1997), Ayal and Karras (1998), and Nelson and Singh (1998) have not found statistically significant relationships between the rate of economic growth and government size. However, a closer look suggests Gordon and Wang have not actually done a survey inasmuch as only the Agell et al. study is relevant here. Agell et al. show the negative bivariate correlation between government size and growth disappears when controlling for initial GDP and demography, as described above. The others should not be included in this class of studies. Nelson and Singh (1998) look only at less developed countries; and Ayal and Karras (1998) study the correlation between various components of economic freedom and the annual growth rate of GDP per capita over the period 1975-90, thereby testing the relationship between government size and economic growth only implicitly, because some measures of government size are included in the economic freedom index they use. ${ }^{12}$

Finally, while there is close to a consensus on the sign of the correlation, there is also consensus on the fact that causality is very hard to establish with certainty using the method of instrumental variable estimation - or any other method currently available. In fact, it is close to conceptually meaningless to discuss a causal effect from an aggregate such as government size on economic growth. Thus, scholars like Kneller et al. (1999) and Bassanini et al. (2001) have in our view rightly concluded it is more fruitful to analyze separately the mechanisms through which different taxes and expenditure affect growth. Not all taxes are equally harmful, and some studies identify public spending on education and public investment to be positively related to growth.

\section{Combining high growth and high taxes? Explaining the flight of the Swedish bumblebee}

Table 6 reports average annual growth of GDP per capita for the period 1995-2004 as well as total tax revenue as a share of GDP in 1995 for the fourteen OECD countries that typically are used in welfare state research. ${ }^{13}$ Clearly, Sweden and the Scandinavian countries stand out by combining high growth and high taxes.

\footnotetext{
12 They do find various aspects of economic freedom linked to growth when controlling for initial income, investment, and population growth. Six elements of economic freedom are shown to be significantly correlated with multifactor productivity and capital accumulation: Low money growth rate, a small role played by government enterprises, rare negative real interest rates, small difference between official and black market exchange rates, large size of the traded-goods sector, and freedom of citizens to engage in capital transactions with foreigners. ${ }^{13}$ We follow Bradley et al. (2003) who stay close to Esping-Andersen's (1990) classification by using three categories. This is standard in welfare state research, though there is much less agreement on the appropriate labels of different categories. In particular, the labels Scandinavian, universal, institutional, encompassing and social democratic all refer to the same countries.
} 
Table 6. Average annual growth of GDP per capita 1995-2004, taxes and economic freedom in different types of welfare states

\begin{tabular}{lrrrr}
\hline $\begin{array}{l}\text { Welfare } \\
\text { state type }\end{array}$ & Growth $(\%)$ & $\begin{array}{r}\text { Taxes } \\
\text { (\% of GDP) }\end{array}$ & EFI & EFI2-5 \\
\hline $\begin{array}{l}\text { Scandinavian } \\
\text { Sweden }\end{array}$ & 2.70 & 47.5 & 7.14 & 8.28 \\
Finland & 3.40 & 45.7 & 7.32 & 8.48 \\
Norway & 2.30 & 40.9 & 7.34 & 8.39 \\
Denmark & 1.70 & 48.8 & 7.46 & 8.56 \\
Average & 2.50 & 45.7 & 7.32 & 8.43 \\
& & & & \\
Continental & & & & \\
Germany & 1.20 & 37.2 & 7.52 & 8.30 \\
France & 1.70 & 42.9 & 6.80 & 7.69 \\
Belgium & 1.80 & 43.6 & 7.26 & 8.06 \\
Netherlands & 2.10 & 41.5 & 7.80 & 8.55 \\
Italy & 1.10 & 40.1 & 6.50 & 7.19 \\
Switzerland & 1.10 & 27.7 & 7.96 & 8.35 \\
Average & 1.50 & 38.8 & 7.30 & 8.02 \\
& & & & \\
Anglo-Saxon & & & & \\
Canada & 2.30 & 35.6 & 7.90 & 8.42 \\
Australia & 2.40 & 28.8 & 7.80 & 8.33 \\
UK & 2.50 & 34.0 & 8.04 & 8.69 \\
US & 2.10 & 27.9 & 8.32 & 8.68 \\
Average & 2.30 & 31.6 & 8.01 & 8.53 \\
\hline
\end{tabular}

Source: Growth from OECD (2009a) and taxes from OECD (2009b). Taxes and economic freedom refer to 1995 levels. The Economic Freedom Index (EFI) indicates how market-friendly institutions and policies are on a scale from 0 to 10. Data are taken from the 2010 dataset available with documentation at www.freetheworld.com. EFI2-5 excludes government size from the index, thereby acting as a summary of legal quality, monetary policy, freedom to trade and regulations of the economy

There is no agreement in the literature how to best explain the growth performance of the Scandinavian welfare states. Sweden particularly is often mentioned as a puzzle, demonstrated for example by the IMF-report entitled "Sweden's Welfare State: Can the Bumblebee Keep Flying?" (Thakur et al. 2003), or the way Lindert (2004) uses the case of Sweden to argue the welfare state is a free lunch.

Yet to a degree the explanation can be found in the empirical research examined in the previous section. Welfare states with high taxes can compensate negative growth effects from large government by applying other growth-promoting policies. The validity of this explanation may be hinted at by the way Scandinavian welfare states since the mid 1990s have been characterized by very market oriented policies and institutions, as evidenced by the values of the economic freedom index shown in Table 5 . This is an especially promising line of inquiry if the first dimension of the economic freedom index, measuring size of government, is excluded. This is shown in the column labels EFI2-5, indicating a summary statistic of legal quality, monetary policy, freedom to trade and regulations of the economy

Another possibility is that countries with the capacity to successfully develop and sustain large government sectors are actually more likely to do so, and that some background factors are required for these countries to sustain larger government sectors. Recent research points to norms like social trust as one such factor explaining why some countries can successfully develop larger welfare states. 


\subsection{Compensating for high taxes using other policies}

The idea that countries with large governments compensate for negative growth effects of high taxes and of public spending by applying growth-friendly policies in other areas, fits well with the development in the Scandinavian countries during the 1980s and the 1990s. To illustrate this point, Table 7 compares Sweden and the US based on data and coefficients from Bergh and Karlsson (2010). For the variables found to robustly explain growth during the 1970-2005 period, the table reports the quantified growth effects of the changes in Sweden and the US between 1980 and $2000 .^{14}$

Table 7. The growth effects of changes in key factors in Sweden and the US between 1980 and 2000

\begin{tabular}{lrrrrrr}
\hline Factor & $\begin{array}{r}\text { Sweden } \\
1980\end{array}$ & $\begin{array}{r}\text { Sweden } \\
2000\end{array}$ & $\begin{array}{r}\text { Effect of } \\
\text { change on } \\
\text { avg. growth }\end{array}$ & $\begin{array}{r}\text { US } \\
1980\end{array}$ & $\begin{array}{r}\text { US } \\
2000\end{array}$ & $\begin{array}{r}\text { Effect of } \\
\text { change on } \\
\text { avg. growth }\end{array}$ \\
\hline $\begin{array}{l}\text { Inflation (\%) } \\
\begin{array}{l}\text { Savings } \\
\text { (\% of GDP) }\end{array}\end{array}$ & 10.5 & 0.5 & 1.7 & 8.9 & 2.5 & 1.1 \\
$\begin{array}{l}\text { Labor force } \\
\text { growth (\%) }\end{array}$ & 0.9 & 0.1 & -0.2 & 2.7 & 1.5 & -0.3 \\
$\begin{array}{l}\text { Taxes } \\
\text { (\% of GDP) }\end{array}$ & 47 & 52 & -0.5 & 25.8 & 29.1 & -0.3 \\
$\begin{array}{l}\text { Unemployment } \\
(\%)\end{array}$ & 2.0 & 6.6 & -0.5 & 6.8 & 4.6 & 0.2 \\
$\begin{array}{l}\text { Exports } \\
(\% \text { of GDP) }\end{array}$ & 28 & 42 & 0.6 & 8.7 & 11.1 & 0.1 \\
$\begin{array}{l}\text { EFI4 } \\
\text { (index, 0-10) }\end{array}$ & 6.8 & 8.6 & 0.005 & 7.8 & 8.0 & 0.0006 \\
\hline
\end{tabular}

Sweden seems to have benefited substantially from reducing inflation, and also from increasing exports. These two factors together increase the annual growth rate by 2.3 percentage points, according to the estimates. Despite being robust in the BACE-analysis, the economic freedom index measure of free trade appears economically insignificant. This is because the index weighs trade flows (picked up by exports) together with trade policies (adding little explanatory value once exports are controlled for).

Higher taxes, higher unemployment and lower labor force growth on average decreased annual growth by 1.2 percentage points between 1980 and 2000. Marginally lower savings is also associated with a small decrease in growth. In all, the analysis suggests Sweden in 2000 increased annual growth by about 1 percentage point due to changes in the variables found robustly related to growth in the study. ${ }^{15}$ The corresponding number for the US is 0.5 percentage points. The difference is explained mainly by the US over the same time period having had a smaller decrease in inflation and a smaller increase in exports

Naturally, these interpretations of regression coefficients serve only an illustrative purpose and should be interpreted with caution. Still, to improve our understanding of growth differences between rich countries, it is useful to put estimated coefficients in perspective by looking at how key variables have

\footnotetext{
${ }^{14}$ We omit the policy irrelevant initial relative income variable from the table. The coefficients are taken from table 6 in Bergh and Karlsson (2010) with tax income as the measure of government size.

${ }^{15}$ It is also worth noting that the results suggest that Sweden can increase growth even more if the functioning of the labor market is improved, as both higher unemployment and lower labor force growth retard growth.
} 
changed in specific countries over time. In this specific case, it seems part of Sweden's recent growth can be explained by drastically lower inflation. It also seems plausible that since 1980 Sweden as a small and open economy has benefited from increasing economic integration.

While economic openness and free trade are routinely stereo-typed as a threat against the welfare state, ${ }^{16}$ there are a number of theoretical reasons why they may be especially important for countries with big governments. Openness creates greater opportunities for division of labor, enabling not only access to new products, but also to knowledge, technologies, and larger markets. Moreover, as stressed by Iversen (2005) the negative effects of extensive transfers, high tax wedges, and stringent labor market regulations can, at least to some extent, be offset by economic openness which encourages welfare states to specialize in high value-added services.

It seems likely that many reforms in Sweden in the 1980s and the 1990s compensated for the negative effects of high taxes. The Scandinavian countries, as shown in Table 6, also have relatively high levels of economic freedom.

\subsection{Trust, government size and growth}

Social trust, assumed to be a reflection of a deeper social norm, is often quantified using the share of the population in different countries who agree with the proposition 'most people can be trusted.' Recent comparative research findings suggest social trust may be an important reason why the Scandinavian countries can successfully combine growth and high taxes. Simply put, trust demonstrably positively affects both government size and growth.

The strong correlation between social trust and government size is well-known in the literature. Nannestad (2008) claims high trust levels enable countries to solve the collective action dilemma created by their welfare systems. Nannestad's hypothesis is that trust makes universal welfare systems sustainable because people in countries with higher trust are less worried about free riding problems linked to extensive welfare policies. Consequently, trust and trustworthiness of citizens and public bureaucrats minimize problems of tax evasion and public sector inefficiencies. Empirically, the link between trust and tax compliance has been shown by Uslaner (2010) and Torgler (2003).

Nannestad's position also seems tenable when we take into account recent empirical investigations of Bergh and Bjørnskov (2011). They use instrumental variables based on linguistics, constitutional monarchies and temperature in the coldest month of the year to create a measure of "historical trust." Their basic idea is that the cross-country variation in trust explained by these instruments cannot be caused solely by the relatively recent variation in welfare state size. A correlation between historical trust and current welfare state size can therefore not be a result of universal welfare states causing higher trust (as suggested, for example, by Kumlin and Rothstein 2005), but rather suggests that trusting populations are more prone to creating large welfare states. Empirically, the measure of historical trust predicts current variation in both total government size and welfare state size; it is in fact a more robust predictor than other factors such as government ideology and economic openness.

In other words, historical trust levels can be seen as a determinant of the feasibility frontier for government size, explaining why some countries can maintain larger government sectors without detrimental growth effects. Importantly, this does not exclude the possibility that government can become too large - in the sense that the benefits on the margin no longer exceed the costs.

\footnotetext{
${ }^{16}$ See, for example, Martin and Schumann (1997), Strange (1996) and Sinn (1997).
} 
Many studies have also identified a link between trust and growth, with lower transaction costs, lower corruption and higher innovation as plausible and substantively important mechanisms (Knack and Keefer 1995; Knack 1999; Zak and Knack 2001; Uslaner 2008; Dincer and Uslaner 2010). The consensus in the trust-cum-growth literature is not complete, but the overview by Bjørnskov (2009) points persuasively towards a sizeable effect in cross-country regressions. ${ }^{17}$ According to Bjørnskov, the size of the effect in most studies is such that 10 percentage points higher trust is associated with half a percentage point higher annual growth rate. In the Scandinavian countries, about 60 percent agree that most people can be trusted, which can be compared to the OECD average of roughly 40 percent.

A third reason why the condition of trust may be central importance is furnished by Aghion et al. (2010b), who argue that low trust plays a pivotal role, leading voters to demand more detailed regulation of the economy, since they do not trust bureaucrats with discretionary power. This mechanism is verified and extended by Bergh and Bjørnskov (2011) who demonstrate that countries with higher historical trust levels also have lower business and credit market regulations. Conversely, higher trust in the Scandinavian countries may well be an important explanation both for the size of their public sectors as well as for their economic growth. ${ }^{18}$

\section{Concluding remarks}

We have shown that most recent studies published in scientific journals tend to find a negative relationship between total government size and economic growth in rich countries. This stands in stark contrast to scholars such as Lindert (2004) and Madrick (2009), who have argued in book length treatments that there is no tradeoff between economic growth and government size. Studies that disaggregate taxes and expenditure typically seem to find that if the policy objective is economic growth there are two consequences: (i) direct taxes on income are worse than indirect taxes, and (ii) social transfers are worse than public expenditure on investment including human capital, which, if anything, increases growth.

Hence, our results do not imply that government must shrink for growth to increase. There is potential for increasing growth by restructuring taxes and expenditure so that the negative effects on growth for a given government size are minimized. Furthermore, countries tend to cluster to institutions that go well together. As stressed by many observers (e.g., Freeman 1995), the Swedish welfare state can be seen as an economic model defined by a unique mix of institutions. The specific mix of institutions and the emergent idiosyncratic interactions among them are key determinants of economic performance.

Both the Scandinavian and the Anglo-Saxon welfare states seem able to deliver high growth rates for very different levels of government size. This does not mean low-tax countries can increase taxes without expecting negative effects on growth, nor that the various mechanisms by which high taxes distort the economy do not apply in Scandinavia. A more incisive interpretation is that there is

\footnotetext{
${ }^{17}$ It is standard in the literature to check for endogeneity by instrumenting trust. For example, Knack and Keefer (1997) instrument for trust with the share of a country's population belonging to the largest ethnic group, while Dincer and Uslaner (2010) use the share of Nordic, British, and German populations in a state as instruments. For a robustness analysis of the trust-growth relationship, see Beugelsdijk et al. (2004).

${ }^{18}$ Supporting the idea that high trust levels explain large government (rather than the other way round), Yamamura (2011) uses the number of political groups per capita in Japan's 47 prefectures as instrument for government size, and finds that government size, if anything, reduces the level of trust.
} 
something omitted from the analysis that explains how Scandinavian countries combine high taxes and high economic growth. We have suggested two such explanations - compensation using growth

friendly policies and benefits from high historical trust (lack of apprehension) levels - but these at best remain only speculative, with ambiguous policy implications. Even if the debate regarding the existence of a correlation between growth and aggregate government size in rich countries now seems more or less settled, the research on policy change, institutions and growth is progressing rapidly. 


\section{References}

Abdiweli, Ali M. 2003. Institutional Differences as Sources of Growth Differences. Atlantic Economic Journal 31 (4): 348-362.

Afonso, Antonio, and Davide Furceri. 2010. Government Size, Composition, Volatility and Economic Growth. European Journal of Political Economy 26 (4), 517-532.

Agell, Jonas. 1996. Why Sweden's Welfare State Needed Reform. Economic Journal 106 (439): $1760-1771$.

Agell, Jonas, Thomas Lindh, and Henry Ohlsson. 1997. Growth and the Public Sector: A Critical Review Essay. European Journal of Political Economy 13 (1): 33-52.

Agell, Jonas, Henry Ohlsson, and Peter Skogman Thoursie. 2006. Growth Effects of Government Expenditure and Taxation in Rich Countries: A Comment. European Economic Review 50 (1): 211-219.

Aghion, Philippe, Yann Algan, Pierre Cahuc and Andrei Shleifer. 2010. Regulations and Distrust. Quarterly Journal of Economics 125 (3): 1015-1049.

Alesina, Alberto, and Romain Wacziarg. 1998. Openness, Country Size and Government. Journal of Public Economics 69 (3): 305-321.

Arellano, Manuel, and Stephen Bond. 1991. Some Tests of Specification for Panel Data: Monte Carlo Evidence and an Application to Employment Equations. Review of Economic Studies 58 (2): 277297.

Arellano, Manuel, and Olympia Bover. 1995. Another Look at the Instrumental Variable Estimation of Error-Components Models. Journal of Econometrics 68 (1): 29-51.

Armey, Dick. 1995. The Freedom Revolution. Washington: Regnery Publishing.

Asoni, Andrea. 2008. Protection of Property Rights and Growth as Political Equilibria. Journal of Economic Surveys 22 (5): 953-987.

Ayal, Eliezer B., and Georgios Karras. 1998. Components of Economic Freedom and Growth: An Empirical Study. Journal of Developing Areas 32 (3): 327-338.

Bassanini, Andrea, Stefano Scarpetta and Philip Hemmings. 2001. Economic Growth: The Role of Policies and Institutions. Panel Data Evidence from OECD Countries, OECD Economics Department Working Paper No. 283. Paris: OECD.

Barro, Robert J. 1990. Government Spending in a Simple Model of Endogenous Growth. Journal of Political Economy 98 (5): 103-125.

Barro, Robert J. 1997. Determinants of Economic Growth: A Cross-Country Empirical Study. Cambridge, MA: MIT Press.

Barro, Robert J, and Xavier Sala-i-Martin. 2004. Economic Growth. 2nd edition. Cambridge and London: MIT Press.

Berggren, Niclas, and Henrik Jordahl. 2005. Does Free Trade Really Reduce Growth? Further Testing Using the Economic Freedom Index. Public Choice 122 (1-2): 99-114.

Bergh, Andreas, and Christian Bjørnskov. 2011. Historical Trust Levels Predict Current Welfare State Size. Kyklos 64 (1), 1-19.

Bergh, Andreas, and Martin Karlsson. 2010. Government Size and Growth: Accounting for Economic Freedom and Globalization. Public Choice 142 (1-2): 195-213.

Bergh, Andreas, and Nina Öhrn. 2011, Growth Effects of Fiscal Policies: A Critique of Colombier. Mimeo. IFN Working Paper No. 858. Stockholm: Research Institute of Industrial Economics.

Besley, Timothy, and Torsten Persson. 2009. The Origins of State Capacity: Property Rights, Taxation, and Policy. American Economic Review 99(4): 1218-1244.

Besley, Timothy, Torsten Persson and Daniel M. Sturm. 2011. Political Competition, Policy and Growth: Theory and Evidence from the United States. Review of Economic Studies, forthcoming.

Beugelsdijk, Sjoerd, Henri L. F. de Groot and Ton V. van Schaik. 2004. Trust and Economic Growth: A Robustness Analysis. Oxford Economic Papers 56 (1): 118-134.

Bjørnskov, Christian. 2009. Economic Growth. In Handbook of Social Capital, ed. Gert T. Svendsen 
and Gunnar L. H. Svendsen. Cheltenham, UK and Northampton, MA: Edward Elgar.

Blundell, Richard, and Stephen Bond. 1998. Initial Conditions and Moment Restrictions in Dynamic Panel Data Models. Journal of Econometrics 87 (1): 115-143.

Bradley, David, Evelyne Huber, Stephanie Moller, Francois Nielsen, and John D. Stephens. 2003.

Distribution and Redistribution in Postindustrial Democracies. World Politics 55 (4): 193-228.

Buchanan, James M. 1980. Rent-Seeking and Profit-Seeking. In Toward a Theory of the Rent-Seeking Society, ed. James M. Buchanan and Gordon Tullock. College Station, TX: Texas A\&M University Press.

Cameron, David. 1982. On the Limits of the Public Economy. Annals of the Academy of Political and Social Science 459 (1): 46-62.

Colombier, Carsten. 2009. Growth Effects of Fiscal Policies: An Application of Robust Modified MEstimator. Applied Economics 41 (7): 899-912.

Dar, A. Atul, and Saleh AmirKhalkhali. 2002. Government Size, Factor Accumulation, and Economic Growth: Evidence from OECD Countries. Journal of Policy Modeling 24 (7-8): 679-692.

Dawson, John W. 2003. Causality in the Freedom-Growth Relationship. European Journal of Political Economy 19 (3): 479-495.

De Haan, Jakob, and Jan-Egbert Sturm. 2000. On the Relationship between Economic Freedom and Economic Growth. European Journal of Political Economy 16 (2): 215-241.

Dincer, Oguzhan C., and Eric M. Uslaner. 2010. Trust and Growth. Public Choice 142 (1): 59-67.

Doppelhofer, Gernot, Ronald Miller, and Xavier Sala-i-Martin. 2004. Determinants of Long-Term Growth: A Bayesian Averaging of Classical Estimates (BACE) Approach. American Economic Review 94 (4): 813-835.

Doucouliagos, Chris, and Mehmet A. Ulubasoglu. 2006. Economic Freedom and Economic Growth: Does Specification Make a Difference? European Journal of Political Economy 22 (1): 60-81.

Durevall, Dick, and Magnus Henrekson. 2011. The Futile Quest for a Grand Explanation of Long-Run Government Expenditure. Journal of Public Economics, forthcoming.

Esping-Andersen, Gøsta. 1990. The Three Worlds of Welfare Capitalism. Princeton, NJ: Princeton University Press.

Feldstein, Martin. S. 2006. The Effect of Taxes on Efficiency and Growth. NBER Working Paper 12201. Cambridge, MA: National Bureau of Economic Research.

Freeman, Richard B. 1995. The Large Welfare State as a System. American Economic Review 85 (2): $16-21$.

Friedman, Thomas. 2005. The World Is Flat: A Brief History of the Globalized World in the Twentyfirst Century. London: Allen Lane.

Fölster, Stefan, and Magnus Henrekson. 2001. Growth Effects of Government Expenditure and Taxation in Rich Countries. European Economic Review 45 (8): 1501-1520.

Fölster, Stefan, and Magnus Henrekson. 2006. Growth Effects of Government Expenditure and Taxation in Rich Countries: A Reply. European Economic Review 50 (1): 219-222.

Glaeser, Edward L., Rafael La Porta, Florencio Lopez-de-Silanes, and Andrei Shleifer (2004). Do Institutions Cause Growth? Journal of Economic Growth 9 (3): 271-303.

Grier, Kevin B., and Gordon Tullock. 1989. An Empirical Analysis of Cross-National Economic Growth, 1951-80. Journal of Monetary Economics 24 (2): 259-276.

Gordon, Peter, and Lanlan Wang. 2004. Does Economic Performance Correlate with Big Government? Econ Journal Watch 1 (2): 192-221.

Gwartney, James D., Randall G. Holcombe, and Robert A. Lawson. 2004. Economic Freedom, Institutional Quality, and Cross-Country Differences in Income and Growth. Cato Journal 24 (3): 205-233.

Hansson, Pär, and Magnus Henrekson. 1994. A New Framework for Testing the Effect of Government Spending on Growth and Productivity. Public Choice 81 (3-4): 381-401.

Iversen, Torben. 2005. Capitalism, Democracy and Welfare. New York: Cambridge University Press. 
King, Robert G., and Sergio Rebelo. 1990. Public Policy and Economic Growth: Developing Neoclassical Implications. Journal of Political Economy 98 (5): 126-150.

Knack, Stephen. 1999. Social Capital, Growth and Poverty: A Survey of Cross-Country Evidence. World Bank Social Capital Initiative Working Paper No. 7.

Knack, Stephen, and Philip Keefer. 1995. Institutions and Economic Performance: Cross-Country Tests Using Alternative Institutional Measures. Economics and Politics 7 (3): 207-227.

Kneller, Richard, Michael Bleaney and Norman Gemmell. 1999. Fiscal Policy and Growth: Evidence from OECD Countries. Journal of Public Economics 74 (1), 171-190.

Kumlin, Staffan, and Bo Rothstein. 2005. Making and Breaking Social Capital: The Impact of Welfare-State Institutions. Comparative Political Studies 38 (4): 339-365.

Landau, David. 1983. Government Expenditure and Economic Growth: A Cross-Country Study. Southern Economic Journal 49 (3): 783-792.

Levine, Ross, and David Renelt. 1992. A Sensitivity Analysis of Cross-country Growth Regressions. American Economic Review 82 (4): 942-963.

Lindert, Peter H. 2004. Growing Public. Cambridge: Cambridge University Press.

Madrick, Jeff. 2009. The Case for Big Government. Princeton, NJ: Princeton University Press.

Marlow, Michael L. 1986. Private Sector Shrinkage and the Growth of Industrialized Economies. Public Choice 49 (2): 143-154.

Martin, Hans-Peter, and Harald Schumann. 1997. The Global Trap: Globalization and the Assault on Prosperity and Democracy. London and New York: Zed Books.

Mollick, Andre V., and René Cabral. 2011. Government Size and Output Growth: The Effects of "Averaging out". Kyklos 64 (1), 122-137.

Nannestad, Peter. 2008. What Have We Learned About Generalized Trust, If Anything? Annual Review of Political Science 11: 413-437.

Nelson, Michael, A., and Ram D. Singh. 1998. Democracy, Economic Freedom, Fiscal Policy, and Growth in LDCs: A Fresh Look. Economic Development and Cultural Change 46 (3): 677-96.

North, Douglass C. 1987. Institutions, Transaction Costs and Economic Growth. Economic Inquiry 25 (3): 419-428.

OECD. 2009a. Regions at a Glance. 2009 Edition. Paris: OECD.

OECD. 2009b. Revenue Statistics 2009. Paris: OECD.

Olson, Mancur. 1982. The Rise and Decline of Nations: Economic Growth, Stagflation, and Social Rigidities. New Haven, CT: Yale University Press.

Pande, Rohini and Christopher Udry. 2005. Institutions and Development: A View from Below. Yale University, Economic Growth Center Discussion Paper No. 928.

Plosser, Charles I. 1992. The Search for Growth. In Policies for Long-Run Economic Growth: A Symposium Sponsored by the Federal Reserve Bank of Kansas City. Jackson Hole, Wyoming, August 27-29. Kansas City: Federal Reserve Bank of Kansas City.

Rodrik, Dani. 2007. One Economics, Many Recipes: Globalization, Institutions, and Economic Growth. Princeton, NJ: Princeton University Press.

Rodrik, Dani, Arvind Subramanian, and Francesco Trebbi. 2004. Institutions Rule: The Primacy of Institutions over Geography and Integration in Economic Development. Journal of Economic Growth 9 (2): 131-165.

Romer, Paul M. 1986. Increasing Returns and Long-Run Growth. Journal of Political Economy 94 (5): 1002-1037.

Romero-Avila, Diego, and Rolf Strauch. 2008. Public Finances and Long-Term Growth in Europe: Evidence from a Panel Data Analysis. European Journal of Political Economy 24 (1): 172-191.

Roodman, David. 2009. A Note on the Theme of Too Many Instruments. Oxford Bulletin of Economics and Statistics 71 (1): 135-158.

Rose, Andrew K. 2006. Size Really Doesn't Matter: In Search of a National Scale Effect. Journal of the Japanese and International Economies 20 (4): 482-507. 
Sala-i-Martin, Xavier. 1997. I Just Ran 2 Million Regressions. American Economic Review 87 (2): $178-183$.

Saunders, Peter. 1986. What Can We Learn from International Comparisons of Public Sector Size and Economic Performance? European Sociological Review 2 (1): 52-60.

Saunders, Peter. 1988. Private Sector Shrinkage and the Growth of Industrialized Economies: Comment. Public Choice 58 (3): 277-284.

Sinn, Hans-Werner. 1997. The Selection Principle and Market Failure in Systems Competition. Journal of Public Economics 66 (2): 247-274.

Solow, Robert M. 1956. A Contribution to the Theory of Economic Growth. Quarterly Journal of Economics 70 (1): 65-94.

Strange, Susan. 1996. The Retreat of the State: The Diffusion of Power in the World Economy. Cambridge: Cambridge University Press.

Sturm, Jan-Egbert, and Jakob De Haan. 2001. How Robust is the Relationship between Economic Freedom and Economic Growth? Applied Economics 33 (7): 839-844.

Swan, Trevor W. 1956. Economic Growth and Capital Accumulation. Economic Record 32 (2): 334 361.

Thakur, Subhash, Michael Keen, Balázs Horváth, and Valerie Cerra. 2003. Sweden's Welfare State: Can the Bumblebee Keep Flying? Washington: International Monetary Fund.

Torgler, Benno. 2003. Tax Morale, Rule-Governed Behavior and Trust. Constitutional Political Economy 14(2), 119-140.

Uslaner, Eric M. 2008. Where You Stand Depends Upon Where Your Grandparents Sat: The Inheritability of Generalized Trust. Public Opinion Quarterly 72 (4): 725-740.

Uslaner, Eric M. 2010. Tax Evasion, Corruption, and the Social Contract in Transition. In Developing Alternative Frameworks for Explaining Tax Compliance, ed. James Alm, Jorge Martinez-Vazquez, and Benno Torgler. London: Routledge.

Widmalm, Frida. 2001. Tax Structure and Growth: Are Some Taxes Better than Others? Public Choice 107 (3-4): 199-219.

Yamamura, Eiji. 2010. Government Size and Trust. Review of Social Economy, forthcoming.

Yohai, Victor, Werner A. Stahel, and Ruben H. Zamar. 1991. A Procedure for Robust Estimation and Inference in Linear Regression. In Directions in Robust Statistics - Part II, Vol. 34, ed. Werner A. Stahel and Sanford Weisberg. New York: IMA Volumes in Mathematics and Its Application, 365374.

Zak, Paul J., and Stephen Knack. 2001. Trust and Growth. Economic Journal 111 (470), 295-321.

Ziliak, Stephen T., and Deirdre N. McCloskey. 2004. Size Matters: The Standard Error of Regressions in the American Economic Review. Journal of Socio-Economics 33 (5): 527-546. 